University of Montana

ScholarWorks at University of Montana

Ecosystem and Conservation Sciences Faculty

Publications

Ecosystem and Conservation Sciences

10-1-1997

\title{
Consumption of Atmospheric Isoprene in Soil
}

Cory C. Cleveland

The University of Montana, cory.cleveland@umontana.edu

Joseph B. Yavitt

Follow this and additional works at: https://scholarworks.umt.edu/decs_pubs

Part of the Ecology and Evolutionary Biology Commons

Let us know how access to this document benefits you.

\section{Recommended Citation}

Cleveland, Cory C. and Yavitt, Joseph B., "Consumption of Atmospheric Isoprene in Soil" (1997). Ecosystem and Conservation Sciences Faculty Publications. 8.

https://scholarworks.umt.edu/decs_pubs/8

This Article is brought to you for free and open access by the Ecosystem and Conservation Sciences at ScholarWorks at University of Montana. It has been accepted for inclusion in Ecosystem and Conservation Sciences Faculty Publications by an authorized administrator of ScholarWorks at University of Montana. For more information, please contact scholarworks@mso.umt.edu. 


\title{
Consumption of atmospheric isoprene in soil
}

\author{
Cory C. Cleveland, ${ }^{1}$ and Joseph B. Yavitt \\ Department of Natural Resources, Comell University, Ithaca, New York
}

\begin{abstract}
Natural vegetation annually emits $503 \mathrm{Tg} \mathrm{yr}^{-1}$ of isoprene (2-methyl-1,3 butadiene) to the global atmosphere where it reacts very rapidly with hydroxyl radicals and strongly regulates atmospheric chemistry. Current models of the compound's chemical behavior assume the atmosphere is the only significant sink; however, there is evidence that soil may consume isoprene. Here we show through field and laboratory studies that soil exposed to isoprene at low mixing ratios removed isoprene to concentrations below those commonly observed in forest canopies, and that the removal of isoprene was biologically mediated. On the basis of laboratory studies with soil from several different ecosystems worldwide, we provide a first approximation of a global annual soil sink for isoprene of $20.4 \mathrm{Tg} \mathrm{yr}^{-1}$, suggesting a soil sink should be included in models that attempt to describe the effect of isoprene emission on atmospheric chemical processes.
\end{abstract}

\section{Introduction}

Global emission of isoprene from natural vegetation to the atmosphere is $503 \mathrm{Tg} \mathrm{yr}^{-1}\left(1 \mathrm{Tg}=10^{12} \mathrm{~g}\right)$, similar to methane $\left(\mathrm{CH}_{4}\right)$ emissions of $500 \mathrm{Tg} \mathrm{yr}$ (Tyler, 1991), and accounting for more than $50 \%$ of the total annual emissions of volatile organic carbon (VOC) to the atmosphere (Guenther et al., 1995). Isoprene regulates tropospheric chemistry by photochemically reacting with hydroxyl $(\mathrm{OH})$ radicals, and with nitrogen oxides $\left(\mathrm{NO}_{\mathrm{x}}\right)$ to produce tropospheric ozone $\left(\mathrm{O}_{3}\right)$ and urban photochemical smog (Trainer et al., 1987; Chameides et al., 1988). Therefore, there is considerable interest in knowing all sources and sinks affecting the global budget for atmospheric isoprene.

Until recently, the atmosphere has been considered the only significant sink for isoprene (Chameides et al., 1988; Brasseur and Chatfield, 1991). However, because recent studies have demonstrated that soil can be a significant sink for organic atmospheric compounds, it seems possible that isoprene also may be consumed in soil. For example, soil consumes 5-20\% of atmospheric $\mathrm{CH}_{4}$ emissions (Tyler, 1991) and may remove $\sim 30 \%$ of atmospheric methyl bromide $\left(\mathrm{CH}_{3} \mathrm{Br}\right)$ emissions (Shorter et al., 1995) annually. Moreover, isoprene is similar to other volatile organic compounds (e.g., monoterpenes) consumed by soil microorganisms (Trudgill, 1994). In addition, there is ample room in the current global isoprene budget for a soil sink, as emission estimates vary by 2-fold (Guenther et al., 1995).

In this study, we investigated whether soil might be a sink for atmospheric isoprene, and whether this sink is significant

\footnotetext{
${ }^{1}$ Now at Environmental, Population, and Organismal Biology, University of Colorado, Boulder.

Copyright 1997 by the American Geophysical Union.

Paper number 97GL02451.

0094-8534/97/97GL-02451\$05.00
}

in the global budget for atmospheric isoprene. We investigated soil consumption of isoprene at mixing ratios of $<50$ to $\sim 500$ parts per billion by volume (p.p.b.v.) in both laboratory studies and field experiments. Although higher than ambient levels, these concentrations are 100-1000 times lower than those used in previous studies. Field experiments occurred at a 24-acre temperate northern hardwood forest (McGowen) located near Ithaca, NY. The field study was designed to demonstrate that isoprene uptake occurs in situ, and that the sink is strong enough to remove isoprene from the ambient atmosphere. Laboratory experiments were performed with soil obtained from several ecosystems worldwide (Table 1). We expected that soil microorganisms would consume isoprene, and that this phenomenon would vary among soil from different ecosystems.

\section{Methods}

Soil collected per site was placed in airtight polyethylene bags, put on ice and returned to Cornell for analysis within 72 hours of collection. We measured isoprene consumption in the laboratory by placing $35-40 \mathrm{~g}$ of fresh soil into $0.91 \mathrm{~L}$ glass vessels to provide a soil layer of $\sim 0.5 \mathrm{~cm}$. Soil water content was adjusted to $40 \%$ (dry weight basis), vessels were sealed, and initial isoprene headspace concentrations were adjusted to 508 p.p.b.v. by injecting $2 \mathrm{ml}$ of a 230 p.p.m. standard. Vessels had a butyl-rubber septum for gas sampling, and we sampled for 12 hours to determine the time course of isoprene consumption in soil. Unless otherwise indicated, soil incubations were performed in duplicates in the dark at $25^{\circ}$ C. To verify that biological rather than physical processes consumed isoprene, we carried out studies with soil autoclaved three times for 1 hour at $120^{\circ}$, with sterile, distilled water added to restore the desired soil moisture level. Blanks (no soil) were included in each assay to verify that chemical oxidation/leakage was not responsible for declines in isoprene headspace concentrations.

We measured isoprene flux in the field using 1.4- $\mathrm{L}$ nylon static chambers. On each visit, we placed five chambers randomly on the forest floor and packed soil around the outside of each chamber to prevent leakage. An aliquot of isoprene standard was injected into each chamber and mixed thoroughly, and we then collected gas samples in 1-ml glass, gastight syringes every fifteen minutes for an hour. In most cases, initial headspace concentration was $\sim 385$ p.p.b. Measurements were made in the same general area on each visit, but we repositioned chambers to avoid previously disturbed locations. Standards were also prepared in the field and sampled at the beginning and end of each experiment to verify that isoprene removal in the chambers was not due to chemical or physical processes. In addition, we measured soil temperature to a depth of $5 \mathrm{~cm}$ using a thermistor and soil moisture gravimetrically on each visit. Sampling occurred on five dates in 1996 (June 6, June 12, July 22, September 12, 
Table 1. Characteristics of sites and soil.

\begin{tabular}{|c|c|c|c|c|c|c|c|}
\hline Site & $\#$ & Vegetation & Soil type & Depth, cm & $\begin{array}{l}\mathrm{pH} \text { in } \\
\mathrm{H} 2 \mathrm{O}\end{array}$ & $\begin{array}{l}\text { Loss on } \\
\text { ignition, \% }\end{array}$ & $\begin{array}{l}\text { Bulk } \\
\text { density, } \\
\text { g/ } \mathrm{cm}^{3}\end{array}$ \\
\hline Tropical moist forest , Barro Colorado & 1 & mixed deciduous & Oxisol & $0-10$ & 6.20 & 17.92 & 0.85 \\
\hline $\begin{array}{l}\text { Island, Panama, }\left(9^{\circ} 09^{\prime} \mathrm{N}, 79^{\circ} 51^{\prime} \mathrm{W}\right) \text {, } \\
\text { Kursar et al., } 1995\end{array}$ & 2 & mixed deciduous & Alfisol & $0-10$ & 5.54 & 16.59 & 0.85 \\
\hline Tropical dry forest, Bosque Estatal & 3 & mixed deciduous & Mollisol & $0-5$ & 8.07 & 18.15 & 1.3 \\
\hline $\begin{array}{l}\text { de Guanica, Puerto Rico, }\left(18^{\circ} 00^{\prime} \mathrm{N}\right. \\
\left.66^{\circ} 50^{\prime} \mathrm{W}\right), \text { Murphy and Lugo, } 1986\end{array}$ & 4 & mixed deciduous & Mollisol & $5-10$ & 8.08 & 16.92 & 1.3 \\
\hline Temperate forest, Monongahela, & 5 & mixed deciduous & Ultisol & $0-10$ & 3.83 & 17.52 & 0.67 \\
\hline $\begin{array}{l}\text { West Virginia, USA, }\left(39^{\circ} 10^{\prime} \mathrm{N},\right. \\
\left.79^{\circ} 35^{\prime} \mathrm{W}\right), \text { Mattson and Smith, } 1993\end{array}$ & 6 & mixed deciduous & Ultisol & $0-10$ & 3.80 & 14.55 & 0.67 \\
\hline $\begin{array}{l}\text { Temperate Forest, McGowen, } \\
\text { New York, USA, }\left(42^{\circ} 25^{\prime} \mathrm{N}, 76^{\circ} 28^{\prime} \mathrm{W}\right) \text {, } \\
\text { This study }\end{array}$ & 7 & mixed deciduous & Alfisol & $0-5$ & 6.33 & 8.98 & 1.20 \\
\hline $\begin{array}{l}\text { Temperate Forest, Amot, New York, } \\
\left(42^{\circ} 15^{\prime} \mathrm{N}, 76^{\circ} 40^{\prime} \mathrm{W}\right) \text {, This study }\end{array}$ & $\begin{array}{l}8 \\
9\end{array}$ & $\begin{array}{l}\text { mixed deciduous } \\
\text { mixed coniferous }\end{array}$ & $\begin{array}{l}\text { Inceptisol } \\
\text { Inceptisol }\end{array}$ & $\begin{array}{l}0-5 \\
0-5\end{array}$ & $\begin{array}{l}4.43 \\
3.72\end{array}$ & $\begin{array}{l}67.93 \\
35.54\end{array}$ & $\begin{array}{l}1.1 \\
1.1\end{array}$ \\
\hline $\begin{array}{l}\text { Temperate forest, Old Forge, } \\
\text { New York, USA, }\left(43^{\circ} 35^{\prime} \mathrm{N}, 75^{\circ} 00^{\prime} \mathrm{W}\right) \text {, } \\
\text { This study }\end{array}$ & 10 & mixed deciduous & Spodosol & 0.5 & 3.38 & 51.73 & 0.7 \\
\hline Temperate forest, Hubbard Brook, & 11 & mixed deciduous & Spodosol & $0-5$ & 3.42 & 33.19 & 0.7 \\
\hline $\begin{array}{l}\text { New Hampshire, USA, (43ㄷ' } \\
71^{\circ} 45^{\prime} \mathrm{W} \text { ), Huntington et al., } 1989\end{array}$ & 12 & mixed coniferous & Spodosol & $0-5$ & 3.83 & 15.61 & 0.7 \\
\hline $\begin{array}{l}\text { Cultivated land, Comell Plantations, } \\
\text { New York, USA, }\left(42^{\circ} 25^{\prime} \mathrm{N}, 76^{\circ} 28^{\prime} \mathrm{W}\right) \text {, } \\
\text { This study }\end{array}$ & $13-16$ & mixed cultivars & Alfisol & $0-5$ & $5.57-6.93$ & 4.74-9.34 & $1.0-1.2$ \\
\hline $\begin{array}{l}\text { Boreal forest, Nikski, Alaska, USA, } \\
\left(61^{\circ} 00^{\prime} \mathrm{N}, 152^{\circ} 00^{\prime} \mathrm{W}\right) \text {, Shoji et al., } \\
1988\end{array}$ & $\begin{array}{l}17 \\
18\end{array}$ & $\begin{array}{l}\text { mixed coniferous } \\
\text { mixed coniferous }\end{array}$ & $\begin{array}{l}\text { Spodosol } \\
\text { Spodosol }\end{array}$ & $\begin{array}{l}0-5 \\
5-10\end{array}$ & $\begin{array}{l}4.52 \\
4.42\end{array}$ & $\begin{array}{l}63.17 \\
24.32\end{array}$ & $\begin{array}{l}0.32 \\
0.32\end{array}$ \\
\hline
\end{tabular}

Numbers in column 2 correspond to time courses shown in Figure 1.

and October 1), and gas samples were analyzed within two hours of collection.

Isoprene was measured on a gas chromatograph-equipped with a photoionization detector (GC-PID), and a $50 \mathrm{~m}$ fused silica column (Megabore SPB-1, $5 \mathrm{~mm}$ coating). The carrier 'gas was highly purified helium (99.99\%) further purified with three in-line filter systems to remove any trace contaminants from the carrier stream. The gas samples were injected oncolumn using splitless injection. Column temperature was $55^{\circ}$ C, and the retention time of the isoprene was 4.5 minutes with a carrier gas linear velocity of $18.5 \mathrm{~cm} \mathrm{~s}^{-1}$. Isoprene concentration was determined by peak area measured with a peak integrator (Shimadzu, model CR 501). The GC-PID had a detection limit of $\sim 5$ p.p.b., and repeated measurements rarely varied by more than $5 \%$.

We calibrated the instrument periodically using two standards (846 p.p.b.v. and 106 p.p.b.v.), which were produced by multiple dilution in glass flasks containing pure nitrogen $\left(\mathrm{N}_{2}\right)$ by injecting $10 \mathrm{ml}$ of $99.9 \%$ liquid isoprene with a 1.0 microliter syringe into a $10.385 \mathrm{~L}$ glass vessel equipped with two septum ports. The concentration was adjusted for prevailing temperature and atmospheric pressure according to the ideal gas law.

\section{Results}

We verified the consumption of isoprene was biologically mediated: sterile soil consumed $<5 \%$ of the isoprene added to the headspace after $24 \mathrm{hr}$, while $>95 \%$ of the isoprene added to blanks (no soil) remained $24 \mathrm{hr}$ later. In addition, fresh soil consumed isoprene with maximum uptake rates at 25 to $35^{\circ} \mathrm{C}$, which is further evidence for biological processes (Paul and
Clark, 1991). We also isolated a soil bacterium in the genus Arthrobacter able to use isoprene as a sole carbon source (Cleveland, 1997).

Soil from different ecosystems consumed isoprene under laboratory conditions (Figure 1). Soil displaying high initial isoprene deposition velocities $(k)$ were moist $(>35 \%$ dry weight) and rich in organic matter (i.e. $>15 \%$ loss on ignition). Values of $k$ were considerably lower in soil from the tropics and temperate agricultural systems, which were drier and relatively low in organic matter.

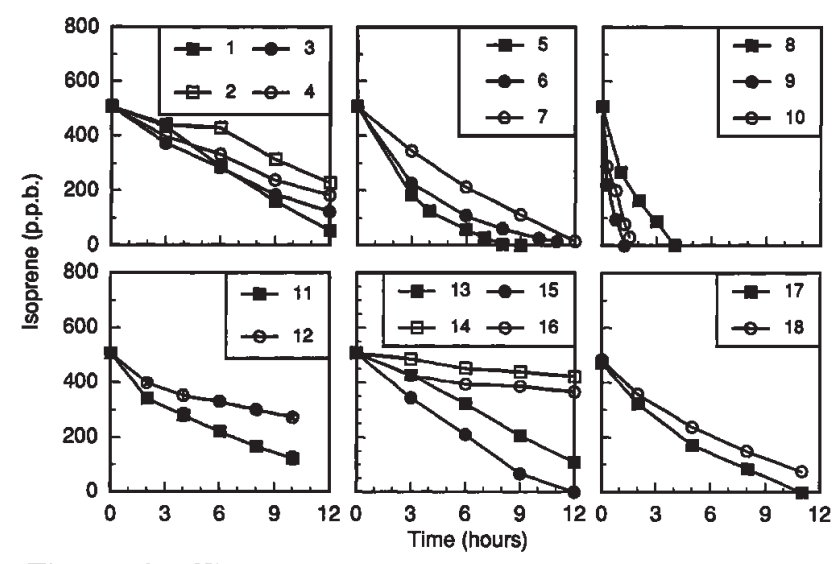

Figure 1. Time course of isoprene consumption in $40 \mathrm{~g}$ fresh soil from: $1 \mathrm{BCI}$ (oxisol); 2 BCI (alfisol); 3 Guanica (0-5 cm); 4 Guanica (5-10 cm); 5-6 Monogahela; 7 McGown; 8 Old Forge; 9 Amot (coniferous); 10 Amot (deciduous); 11 Hubbard Brook (deciduous); 12 Hubbard Brook (coniferous); 13-16 Plantations; 17 Nikiski $(0-5 \mathrm{~cm}) ; 18$ Nikiski $(5-10 \mathrm{~cm})$. 
Table 2. Total estimated isoprene consumption in soil worldwide.

\begin{tabular}{|c|c|c|c|c|c|c|}
\hline Biome type & $\begin{array}{c}\text { Afea } \\
\left(\times 10^{6} \mathrm{~km}^{2}\right)\end{array}$ & $\begin{array}{c}\text { Active } \\
\text { season, } \\
\text { days }\end{array}$ & $\underset{\left(\min ^{-1}\right)}{\mathbf{k}}$ & $\left(x 10^{-5} \min ^{\mathbf{k}^{*}} \sum \mathrm{gdw}^{-1}\right)$ & $\begin{array}{l}\text { Isoprene flux } \\
\left(\mathrm{g} \Sigma \mathrm{km}^{-2} \mathrm{day}^{-1}\right)\end{array}$ & $\left(10_{\mathrm{g}}^{\text {Total }} \mathrm{yr}^{-1}\right)$ \\
\hline Tropical rain forest & 17 & 365 & $0.000645 \pm 0.000118$ & $1.94 \pm 0.34$ & $72.7 \pm 12.7$ & $0.45 \pm 0.078$ \\
\hline Temperate deciduous forest & 7 & 270 & $0.00738 \pm 0.00451$ & $25.1 \pm 13.7$ & $1197 \pm 653$ & $2.26 \pm 0.12$ \\
\hline Temperate coniferous forest & 5 & 270 & $0.010138 \pm 0.008072$ & $155 \pm 143$ & $9579 \pm 8837$ & $12.93 \pm 11.93$ \\
\hline Boreal forest & 12 & 110 & 0.00203 & 203 & 2862 & 3.77 \\
\hline Tropical seasonal forest & 7.5 & 270 & $0.000848 \pm 0.00031$ & $1.83 \pm 0.68$ & $105 \pm 39$ & $0.21 \pm 0.079$ \\
\hline Cultivated land & 14 & 200 & $0.001071 \pm 0.000331$ & $4.62 \pm 0.96$ & $265 \pm 55$ & $0.74 \pm 0.15$ \\
\hline Total & & & & & & $20.4 \pm 13.5$ \\
\hline
\end{tabular}

$k$ is mean of the observed initial isoprene deposition velocities into soil from each ecosystem, and stated errors represent \pm 1 SE of the mean.

Here isoprene flux values are normalized to an average isoprene mixing ratio of 3 p.p.b.

Soil in the field consumed isoprene to concentrations below our detection limit within one hour, while standards prepared and sampled in the field showed no detectable change in isoprene consumption over the course of each experiment; hence, isoprene loss was not due to chemical oxidation with $\mathrm{OH}$ in the chambers. Initial deposition velocities in the chambers ranged from $-0.0126 \pm 0.0034$ to $-0.0478 \pm 0.0017$ $\mathrm{min}^{-1}$ with consumption rates ranging from $10.08 \pm 0.45$ to $40.77 \pm 1.30 \mathrm{nmol} \mathrm{m}^{-2} \min ^{-1}$ (mean $=23.82 \pm 5.09 \mathrm{nmol} \mathrm{m}$ min ). In a concurrent study of $\mathrm{CH}_{4}$ consumption at this site, the diffusive loss rate of a relatively inert $\mathrm{CH}_{3} \mathrm{~F}$ was -0.0016 $\mathrm{min}^{-1}$, indicating that diffusion alone was not responsible for isoprene loss in the chambers (Hudgens and Yavitt, 1997). Flux rates (and $k$ values) increased gradually through the summer, with the highest values in late summer (September 12) and lowest values on the final sampling date (October 1) following leaf senescence. The decrease from September to October coincided with an increase in soil moisture from $28 \%$ to $45 \%$ (dry weight basis) and a decrease in soil temperature from 17.8 to $13.5^{\circ} \mathrm{C}$. Isoprene flux rates did not show a strong correlation with temperature $(r=0.46)$, but did exhibit a relatively strong negative relationship with soil moisture ( $\mathrm{r}$ $=-0.91$ ). A multiple linear regression showed that soil moisture and temperafure together were good predictors of isoprene uptake rate $\left(\mathrm{r}^{2}=0.85\right)$ in the field.

\section{Discussion}

This study provides strong evidence for a biological sink for atmospheric isoprene in soil. Our field studies with static chambers confirm this sink is strong enough to reduce atmospheric isoprene to levels lower than those commonly observed in forest canopies (< 3-10 p.p.b.v.) (Rasmussen and Khalil, 1988; Zimmerman et al., 1988; Baldocchi et al., 1995). The apparent seasonal pattern, with a late summer maximum for isoprene consumption, closely resembles the seasonal pattern for emission of VOCs (Tingey et al., 1991; Goldstein et al., 1996). This intriguing correspondence suggests a link between rates of isoprene emission and consumption, as isoprene emission rate is a function of leaf area, which tends to increase through the growing season (Monson et al., 1991). This is noteworthy because the atmosphere may be a less effective sink for isoprene removal in the autumn when atmospheric $\mathrm{OH}$ concentrations decrease
(Goldstein et al., 1995).

Soil moisture strongly affected isoprene consumption in the field, which agrees with many other studies of microbial oxidation of atmospheric trace gases (Conrad, 1996). Soil moisture affects the amount of water available to microorganisms, as well as substrate diffusion, osmotic potential, and $\mathrm{O}_{2}$ availability (Conrad, 1996). In contrast, no. clear relationship between temperature and the isoprene flux rate, even though microbial activity in soil does vary with soil temperature (Paul and Clark, 1989; Lloyd and Taylor, 1994), may reflect the relatively narrow temperature range during the growing season (i.e., $13.5^{\circ} \mathrm{C}$ to $18^{\circ} \mathrm{C}$ ).

Our laboratory studies confirm that soil from several different ecosystems can consume atmospheric isoprene, and that consumption occurs at different rates in soil from different ecosystems (Figure 1). We put these results into perspective by calculating potential isoprene consumption per biome using the following equation:

$$
\begin{aligned}
& \text { Consumption ( } \left.\mathrm{g} \text { isoprene } \mathrm{yr}^{-1}\right)=\left(\mathrm{k}^{*}\right)\left(\mathrm{c}_{\mathrm{i}}\right)\left(\mathrm{S}_{\mathrm{a}}\right) \text { (B.D.) } \\
& \left(1 \times 10^{10} \mathrm{~cm}^{2} \mathrm{~km}^{-2}\right)\left(1440 \mathrm{~min} \mathrm{~d}^{-1}\right) \text { (area) (active season) }
\end{aligned}
$$

where: $k^{*}$ is the mean of all initial isoprene deposition velocities determined from laboratory incubations for soil sampled from a specific biome type (see Table 2); $c_{i}$ is an isoprene mixing ratio of 3 p.p.b.v. $\left(=0.0000002044 \mathrm{~g} \mathrm{~L}^{-1}\right)$; $S_{\mathrm{a}}$ is an active soil depth of $3 \mathrm{~cm}$; B.D. is soil bulk density in $\mathrm{g} / \mathrm{cm}^{3}$; area is biome area in $\mathrm{km}^{2}$ ); and, active season is growing season length in days.

Accordingly, we estimate soil may consume $20.4 \mathrm{Tg}$ of atmospheric isoprene per year, which is $\sim 5 \%$ of the $400 \mathrm{Tg}$ of isoprene emitted annually from the ecosystems we investigated (Table 2). This is very similar in magnitude to the soil sink for atmospheric $\mathrm{CH}_{4}$ of 5-20\% (Tyler, 1991).

We suspect our assumptions produce an "upper bound" on the soil sink for isoprene for several reasons. The average mixing ratio of isoprene may be lower than 3 p.p.b.v. in many forest canopies. There have been relatively few studies investigating isoprene concentrations near and below forest canopies, although 3 p.p.b.v. seems reasonable (Rasmussen and Khalil, 1988; Baldocchi et al., 1995). We also believe a 3 $\mathrm{cm}$ active soil layer is justifiable, even though isoprene consumption may be most vigorous in the top $1 \mathrm{~cm}$ of the soil. However, it is notable that soil up to $15 \mathrm{~cm}$ deep 
consumed isoprene in some ecosystems (Figure 1). Next, we assumed a 24 hour day in our calculations because several studies show that isoprene is detectable in forest canopies even when emission is not occurring (Rasmussen and Khalil, 1988; Zimmerman et al., 1988), and because our field and laboratory experiments revealed that isoprene consumption occurs in the dark, However, it is true that isoprene concentrations are highest during daytime when peak production occurs, and consumption may decline at night as isoprene concentrations decrease. Biome classifications, corresponding areas, and active seasons come from an estimate of global isoprene emissions by Rasmussen and Khalil (1988). Season length is provided because biogenic isoprene is only produced during the growing season, and because active microbial uptake is diminished in temperate and boreal regions when soil is frozen (Paul and Clark, 1991).

Despite potential shortcomings, these assumptions provide a reasonable basis for the first estimate of isoprene consumption in soil on a large scale, and our estimate suggests that the process is a significant component of the global isoprene budget.

Conversely, the much higher $k$ values in our field studies than in the laboratory assays suggests our estimate of isoprene consumption on a global basis may be conservative. A more robust estimate requires an examination of the process at the soil/atmosphere interface in all of the pertinent ecosystems and its seasonal dynamics. Clearly, spatial heterogeneity of microbial communities in landscapes is extremely variable, which makes scaling of biogeochemical processes difficult (Madsen, 1996). For example, the $k$ value in soil from an old growth forest site in the Adirondack Mountains in New York was -0.48 , or more than two orders of magnitude higher than in any other soil. This site had a thick organic-rich forest floor layer, suggesting isoprene consumption could be more important in sites which have been relatively undisturbed by human activities that alter soil properties. In addition, microbes in soil taken from the field may change rapidly in response to altered environmental and physiological conditions imposed by sampling and laboratory incubation (Madsen, 1996). However, in both field and laboratory components of this study, the evidence for a soil sink for isoprene is robust. Therefore, we recommend further studies to increase the accuracy of this estimate, and eventual recognition in models which attempt to describe the effect of isoprene emission on atmospheric chemical processes.

Acknowledgments. We thank Tim Fahey, Eugene Madsen and reviewers for helpful comments on the manuscript.

\section{References}

Baldocchi, D., A. Guenther, P. Harley, L. Klinger, P. Zimmerman, B. Lamb, and $\mathrm{H}$. Westberg, The fluxes and air chemistry of isoprene above a deciduous hardwood forest, Phil. Trans. R. Soc. Lond. A, 350, 279-296, 1995.

Brasseur, G.P., and R.B. Chatfield, The fate of biogenic trace gases in the atmosphere, in Trace Gas Emissions by Plants, edited by T.D. Sharkey, E. A. Holland, and H. A. Mooney, Pp. 1-27, Academic, San Diego, Calif., 1991.

Chameides, W.L., R.W. Lindsay, J. Richardson, and C.S. Kiang, The role of biogenic hydrocarbons in urban photochemical smog: Atlanta as a case study, Science, 241, 1473-1475, 1988.

Cleveland, C.C., Consumption of atmospheric isoprene in soil, M.S. Thesis, 90 pp., Comell University, Ithaca, N.Y., May 1997.
Conrad, R., Soil microorganisms as controllers of atmospheric trace gases $\left(\mathrm{H}_{2}, \mathrm{CO}, \mathrm{CH}_{4}, \mathrm{OCS}, \mathrm{N}_{2} \mathrm{O}\right.$, and NO), Microbiol. Rev., 60, 609$640,1996$.

Goldstein, A.H., S.M. Fan, M.L. Goulden, J.W. Munger, and S.C. Wofsy, Emissions of ethene, propene, and 1-butene by a midlatitude forest, J. Geophys. Res., 101, 9149-9157, 1996.

Goldstein, A.H., S.C. Wofsy, and C.M. Spivakovsky, Seasonal variations of nonmethane hydrocarbons in rural New England: Constraints on $\mathrm{OH}$ concentrations in northem midlatitudes, J. Geophys. Res., 100, 21,023-21,033, 1995.

Guenther, A., C.N. Hewitt, D. Erickson, R. Fall, C. Geron, T. Graedel, P. Harley, L. Klinger, M. Lerdau, W.A. McKay, T. Pierce, B. Scholes, R. Steinbrecher, R. Tallamraju, J. Taylor, and P. Zimmerman, A global model of natural volatile organic compound emissions, J. Geophys. Res., 100, 8873-8892, 1995.

Hudgens, D.E., and J.B. Yavit, Land use effects on soil methane and carbon dioxide fluxes in forests near Ithaca, NY, Ecoscience, 4, 214-222, 1997.

Huntington, T.G., C.E. Johnson, A.H. Johnson, T.G Siccama, and D.F. Ryan, Carbon, organic matter, and bulk density relationships in a forested spodosol, Soil Sci., 148, 380-386, 1989.

Kursar, T.A., S.J. Wright, and R. Radulovich, The effects of the rainy season and irrigation on soil water and oxygen in a seasonal forest in Panama, J. Trop. Ecol., 11, 497-516, 1995.

Lloyd, J., and J.A. Taylor, On the temperature dependence of soil respiration, Funcl. Ecol., 8, 315-323, 1994.

Madsen, E.L., A critical analysis of methods for determining the composition and biogeochemical activities of soil microbial communities in situ, in Soil Biochemistry, edited by G. Stotzky, and J. Bollag, pp. 287-370, Marcel Dekker, New York, 1996.

Mattson, K.G., and H.C. Smith, Detrital organic matter and soil $\mathrm{CO}_{2}$ efflux in forests regenerating from cutting in West Virginia, Soil Biol. Biochem., 25, 1241-1248, 1993.

Monson, R.K., A.B. Guenther, and R. Fall, Physiological reality in relation to ecosystem- and global-level estimates of isoprene emission, in Trace Gas Emissions by Plants, edited by T.D. Sharkey, E. A. Holland, and H. A. Mooney, pp. 185-207, Academic, San Diego, Calif., 1991.

Murphy, P.G., and A.E. Lugo, Structure and biomass of a subtropical dry forest in Puento Rico, Biotropica, 18, 89-96, 1986.

Paul, E.A., and F.E. Clark, Soil Microbiology and Biochemistry, 273 pp., Academic, New York, 1989.

Rasmussen, R.A., and M.A.K. Khalil, Isoprene over the Amazon Basin, J. Geophys. Res., 93, 1417-1421, 1988.

Shoji, S, T., Takahashi, T. Ito, and C.L. Ping, Properties and classification of selected volcanic ash soils from Kenai peninsula, Alaska, Soil Sci., 145, 395-410, 1988.

Shorter, J.H., C.E. Kolb, P.M. Crill, R.A. Kerwin, R.W. Talbot, M.E. Hines, and R.C. Harriss, Rapid degradation of atmospheric methyl bromide in soils, Nature, 377, 717-719, 1995.

Tingey, D.T., D.P. Tumer, and J.A. Weber, Factors controlling the emissions of monoterpenes and other volatile organic compounds, in Trace Gas Emissions by Plants, edited by T.D. Sharkey, E. A. Holland, and H. A. Mooney, pp. 93-119. Academic, San Diego, Calif., 1991.

Trainer, M., E.J. Williams, D.D. Parrish, M.P. Buhr, E.J. Allwine, H.H. Westberg, F.C. Fehsenfeld, and S.C. Liu, Models and observations of the impact of natural hydrocarbons on rural ozone, Nature, 329, 705$707,1987$.

Trudgill, P.W., Microbial metabolism and transformation of selected monoterpenes, in Biochemistry of Microbial Degradation, edited by C. Ratledge, Kluwer Academic, The Netherlands, 1994.

Tyler, S.C., The global methane budget, in Microbial Production and Consumption of Greenhouse Gases: Methane, Nitrogen Oxides and Halomethanes, edited by J.E. Rogers, and W. B. Whitman, pp. 7-38, Am. Soc. Microbiol., Washington, D.C., 1991.

Zimmerman, P.R., J.P. Greenberg, and C.E. Westberg, Measurements of atmospheric hydrocarbons and biogenic emission fluxes in the Amazon boundary layer, J. Geophys. Res., 93, 1407-1416, 1988.

C.C. Cleveland and J.B. Yavitt, Department of Natural Resources, Comell University, Ithaca, NY 14853. (e-mail: jby1@comell.edu)

(Received February 28, 1997; revised May 16, 1997; accepted July 30, 1997) 